\title{
Pengaruh Zikir al-Ma'tsurat dan Terjemahannya Terhadap Penurunan Kecemasan Siswa Menghadapi Ujian Nasional ${ }^{1}$
}

\author{
Nur Jannah ${ }^{2}$ \\ Universitas Islam Negeri (UIN) Antasari
}

\begin{abstract}
The problems most often experienced by students when facing the National Exam is anxiety problems. Anxiety arises because students are burdened by thoughts and shadows of possibilities that occur when failing in the National Exam. Excessive anxiety will cause students not to focus on the National Exam. One way that can be done to provide peace of mind in the Islamic view is with dhikr. In contrast to most schools, SMPIT Ukhuwah Banjarmasin not only prepares students in the outer field such as additional subjects are tested, but the school also prepares the spiritual condition of students by giving the program of recitation of al-Ma'tsurat recitation that is read every afternoon. But the recitation of the dhikr is not with the translation. The reading of al-Ma'tsurat dhikr with its translation will invite the students to be more solemn and understand the content contained in the recitation of the dhikr. This study aims to determine the level of student anxiety and find out whether the dhikr al-Ma'tsurat and its translation have an effect on the decreasing anxiety of students facing the National Exam at SMPIT Ukhuwah Banjarmasin.
\end{abstract}

This research is experimental research and data is presented with quantitative approach. Variable in this research there are 2 that dhikr al-Ma'tsurat and translation $(X)$ and anxiety $(Y)$. While the design of this study using the design pretest and posttest one group. Data collection tools in the form of anxiety scale The sampling technique used is purposive sampling, with the number of subjects as many as 7 students. Data analysis using t-test.

The results of quantitative data indicate a decrease in anxiety between before the intervention (pretest) and after intervention (postest) is done, the scoring of the anxiety category from high to medium and low anxiety categories. And the decline of a large minimum value of 32.00 and the maximum value of 24.00, and the mean value of 24.7147. The result of the normality prerequisite test is $p>0,05$ indicating that the data distribution at initial and final test is normal. The result of $t$-test is obtained t value $=11,068$ and $p=0,000, p<0,01$, meaning dhikr al-Ma'tsurat and its translation can influence decreasing anxiety of student facing National Exam at SMPIT Ukhuwah Banjarmasin.

Kata kunci: Zikir al-Ma'tsurat; Kecemasan; Siswa SMP; Ujian Nasional.

\footnotetext{
${ }^{1}$ Tulisan ini di dasarkan pada skripsi penulis pada Jurusan Psikologi Islam Fakultas Ushuluddin dan Humaniora IAIN Antasari.

${ }^{2}$ Korespondensi untuk tulisan ini ditujukan kepada email norjannah121@gmail.com
} 


\section{Pendahuluan}

Ujian Nasional merupakan salah satu bagian penting dari proses pendidikan di Indonesia. Ujian Nasional merupakan bagian dari tes standarisasi yang artinya format soal dan kriteria penilaian ditentukan oleh pusat dan diberlakukan dalam satuan wilayah yang cakupannya luas. Ujian Nasional sejak lama sudah menjadi momok yang menakutkan bagi siswa. Tes yang diadakan di akhir masa studi ini seakan menjadi penentu keberhasilan siswa selama menempuh pendidikan.

Tidak jarang Ujian Nasional dapat menimbulkan kecemasan di kalangan siswa SMP atau sekolah-sekolah sederajat. Kecemasan tersebut muncul karena siswa dibebani oleh pikiran dan bayangan kemungkinan-kemungkinan yang terjadi bila gagal dalam Ujian Nasional. Sejumlah resiko yang harus ditanggung siswa bila gagal dalam Ujian Nasional antara lain rasa malu, kerugian waktu, kerugian biaya, harus mengikuti ujian ulangan dan tidak dapat melanjutkan ke jenjang pendidikan yang lebih tinggi. ${ }^{3}$

Kecemasan itu sendiri diartikan sebagai perasaan tidak nyaman, yang terdiri atas respon-respon psikofisik sebagai antisipasi terhadap bahaya yang dibayangkan atau tidak nyata, seolah-olah disebabkan oleh konflik intrapsikis. Biasanya gejala fisik yang menyertainya adalah peningkatan detak jantung, perubahan pernapasan, keluar keringat, gemetar, lemah dan lelah. ${ }^{4}$ Sedangkan gejala psikisnya seperti merasa takut tanpa alasan yang jelas, merasa jengkel terhadap masalah kecil, sulit memutuskan masalah, dan merasa khawatir serta tegang. ${ }^{5}$ Adanya kecemasan dalam diri individu ternyata dapat menimbulkan reaksi-reaksi tertentu, dan masing-masing individu akan memberikan reaksi yang berbeda satu sama lain. Pada dasarnya reaksi kecemasan dapat dibedakan menjadi reaksi fisiologis dan psikologis. ${ }^{6}$

\footnotetext{
${ }^{3}$ Maesaroh and Falah, "Religiusitas Dan Kecemasan Menghadapi Ujian Nasional (UN) Pada Siswa Madrasah Aliyah," Jurnal Proyeksi 6, no. 2 (2011).

${ }^{4}$ Iin Tri Rahayu, Psikoterapi: Perspektif Islam Dan Psikologi Kontemporer (Malang: UIN Malang Press, 2009). 167

${ }^{5}$ Abdul Mujib and JusufMudzakir, Nuansa-Nuansa $\quad$ Psikologi Islam $\quad$ (Jakarta: PT RajaGrafindo Persada, 2002). 170

${ }^{6}$ Iin Tri Rahayu, Psikoterapi: Perspektif Islam Dan Psikologi Kontemporer. 174
} 
Banyak cara yang ditawarkan oleh para psikolog untuk mengatasi kecemasan ini, mulai merubah pola pikir sampai melaksanakan latihan-latihan fisik. Metode yang sangat dikenal dalam dunia psikologi klinis dan konseling untuk mengatasi berbagai gangguan emosional termasuk juga kecemasan adalah relaksasi. Bagi kaum Muslim, obat yang sangat ampuh untuk menghadapi kecemasan adalah apa yang dijelaskan dalam firman-Nya Q.S. al-Ra'd/13: 28 yang artinya: Yaitu orang-orang yang beriman dan hati mereka menjadi tenteram dengan mengingat Allah. Ingatlah hanya dengan mengingat Allah hati menjadi tentram.

Berdasarkan ayat tersebut, terapi untuk menghadapi berbagai kecemasan menurut alQur'an adalah dengan selalu mengingat kepada Allah SWT. Hanya dengan ingat kepada Allah SWT sajalah hati menjadi tentram. Agar bisa merasa tenang, zikir harus betul-betul dilandasi dengan kekhusyukan. Zikir ialah menyebut Allah dengan membaca tasbih, tahlil, tahmid, taqdis, takbir dan membaca doa-doa yang ma'tsur, yaitu doa-doa yang diterima dari Nabi SAW.7 Berzikir adalah melakukan atau membaca bacaan yang suci yang menyebabkan seseorang ingat kepada Allah SWT dengan segala kebesaran-Nya. Ada juga yang mendefinisikan zikir sebagai kesadaran merasa berhubungan dengan Allah SWT. ${ }^{8}$ Zikir adalah sebuah aktifitas ibadah dalam umat muslim untuk mengingat Allah, di antaranya dengan menyebut dan memuji nama Allah, dan zikir adalah satu kewajiban yang tercantum dalam al-Qur'an. ${ }^{9}$

Zikir dan doa berhubungan dengan proses mengingat dan proses pengungkapan perasaan. Dengan berzikir seseorang dapat mengingat Allah SWT. dan mengingat dosadosanya atau pengalaman yang telah lalu. Dengan berdoa seseorang dapat mengugkapkan perasaannya kepada Allah SWT sehingga ketenangan jiwa didapat di dalamnya. ${ }^{10}$

Dr. Abdurrahman al-Isawa pernah melakukan studi lapangan terhadap sekelompok pelajar Arab untuk mengetahui seberapa jauh keresahan dan kegelisahan mereka terhadap ujian sekolah. Adapun hasil dari studi lapangan yang dilakukan oleh Dr. Abdurrahman adalah bahwa separuh dari mereka merasakan keresahan dan kegelisahan sampai pada

\footnotetext{
${ }^{7}$ Teungku Muhammad Hasbi Ash Shiddieqy, Pedoman Dzikir Dan Do'a (Semarang: PT Pustaka Rizki Putra, 2002). 4

8 Achmad Mubarok, Psikologi Qur'ani (Pustaka Firdaus, 2001). 124

${ }_{9}^{9}$ Wikipedia, "Zikir," accessed November 9, 2015, https://id.m.wikipedia.org/wiki/zikir.

${ }^{10}$ AF Jaelani, Penyucian Jiwa (Tazkiyat Al-Nafs) \& Kesehatan Mental (Jakarta: Amzah, 2000). 109
} 
batas waktu tertentu. Sepertiga dari mereka merasakan kegelisahan dan keresahan, 30,3\% dari mereka meresakan kegelisahan dan keresahan yang sangat. Sebagian dari mereka bahkan ada yang tertekan dan down. Jumlah persentasi yang merasakan kegelisahan dan keresahan dengan tingkatan yang berbeda sebesar $86,6 \%$ berbanding dengan jumlah mereka yang menyatakan tidak mengalami keresahan dan kegelisan sebesar 13,4\%.11

Berdasarkan hasil observasi awal peneliti mengenai hal ini di SMPIT Ukhuwah Banjarmasin, didapatkan hasil bahwa pihak sekolah telah mempersiapkan siswanya dalam menghadapi Ujian Nasional baik secara lahiriah maupun batiniah. Segi lahiriah misalnya diadakannya jadwal tambahan untuk beberapa mata pelajaran yang akan diujikan, sedangkan dari segi batiniah pihak SMPIT telah melaksanakan program yang berbasis rohaniah selama beberapa tahun belakangan. Salah satunya adalah zikir al-Ma'tsurat yang dibaca pada sore hari untuk siswa kelas VII, VIII dan IX..12

Pembacaan zikir al-Ma'tsurat merupakan kegiatan rutin yang dilakukan oleh siswa yang bersekolah di SMPIT Ukhuwah Banjarmasin, khususnya kelas IX yang akan menghadapi Ujian Nasional, pihak sekolah memberikan kebijakan dengan menerapkan pembacaan zikir al-Ma'tsurat pada sore hari setelah mata pelajaran terakhir. Zikir alMa'tsurat yang biasa dibaca siswa hanya bacaan yang berbahasa arab tanpa membaca terjemahannya.

Asumsi peneliti bahwa pembacaan zikir al-Ma'tsurat yang disertai terjemahannya akan memudahkan siswa lebih khusuk dan menghayati makna yang terkandung di dalam bacaan zikir al-Ma'tsurat tersebut. Zikir al-Ma'tsurat yang biasa dibaca oleh siswa di SMPIT Ukhuwah Banjarmasin berisikan bacaan ayat Al-Qur'an pilihan dan doa-doa dari Rasulullah SAW.

${ }^{11}$ M Sayyid Muhammad Az-Za'balawi, Pendidikan Remaja Antara Islam \& Ilmu Jiwa (Jakarta: Gema Insani, 2007). 539

${ }^{12} \mathrm{Abdurrahman}$, Kepala sekolah SMPIT Ukhuwah Banjarmasin, wawancara pribadi, Banjarmasin, 09 November 2015. 
Berdasarkan uraian tersebut, peneliti tertarik untuk mengkaji lebih jauh dengan melakukan sebuah penelitian ilmiah dengan memberikan perlakuan (intervensi) kepada siswa kelas IX untuk membacakan zikir al-Ma'tsurat dan terjemahannya, untuk mengetahui apakah zikir al-Ma'tsurat yang dibaca dengan terjemahnnya dapat berpengaruh terhadap penurunan kecemasan siswa dalam menghadapi Ujian Nasional.

Tujuan dari dilakukannya penelitian ini adalah untuk mengetahui tingkat kecemasan siswa dalam menghadapi Ujian Nasional di SMPIT Ukhuwah Banjarmasin dan juga untuk mengetahui apakah zikir al-Ma'tsurat dan terjemahannya dapat mempengaruhi penurunan kecemasan siswa menghadapi Ujian Nasional di SMPIT Ukhuwah Banjarmasin.

\section{Metode}

1. Jenis Penelitian

Penelitian ini menggunakan pendekatan kuantitatif eksperimental. Penelitian ini menggunakan desain pretest dan postest satu kelompok atau one group pretest and postest design, yakni penelitian yang dilakukan pada satu kelompok ekperimen tanpa kelompok pembanding, dalam penelitian ini peneliti memberikan pretest kesemua populasi kemudian setelah itu peneliti mengambil sampel dengan karateria yang telah peneliti tentukan, kemudian peneliti memberikan perlakuan atau intervensi kepada sampel yang akan menjadi subjek dalam penelitian ini. Setelah intervensi dilakukan, peneliti akan melakukan postest kepada subjek untuk mengetahui hasilnya.

\section{Lokasi Penelitian}

Lokasi penelitian adalah di SMPIT Ukhuwah Banjarmasin yang beralamat di jalan Bumi Mas Raya Komplek Bumi Handayani XII A RT 28 Banjarmasin.

\section{Subjek dan Objek Penelitian}

Subyek penelitian ini adalah siswa yang telah masuk dalam karekteristik yang telah ditentukan peneliti yakni siswa yang mengalami kecemasan tinggi dan sangat tinggi dalam menghadapi Ujian Nasional, siswa yang berada pada kelas IX di SMPIT Ukhuwah Banjarmasin dan bersedia menjadi responden atau subjek penelitian. Objek penelitian atau variabel dalam penelitian ini ada dua macam variabel yakni 
Variabel Eksperimental $(\mathrm{X}) \quad$ : Zikir al-Ma'tsurat dan terjemahannya

Variabel terikat $(\mathrm{Y}) \quad$ : Kecemasan

4. Populasi, Sampel, dan Metode Pengambilan Sampel

Dalam penelitian ini yang menjadi populasinya adalah siswa kelas IX A dan siswa kelas IX C di SMPIT Ukhuwah Banjarmasin yang berjumlah 53 orang. Dikarenakan siswa kelas IX B dan siswa kelas IX D sudah dijadikan subjek uji validitas dan reliabilitas untuk skala kecemasan yang dibuat oleh peneliti.

Tabel 1

Jumlah Siswa dan Siswi Kelas IX SMPIT Ukhuwah Banjarmasin

\begin{tabular}{ccc}
\hline Kelas & Jenis Kelamin & Jumlah \\
\hline IX A & Perempuan & 25 \\
IX B & Perempuan & 26 \\
IX C & Laki-laki & 28 \\
IX D & Laki-laki & 26 \\
\hline
\end{tabular}

Sampel dalam penelitian ini adalah siswa kelas IX SMPIT Ukhuwah Banjarmasin yang memenuhi karakteristik peneliti. Adapun karakteristik tersebut antara lain: Siswa kelas IX yang menghadapi Ujian Nasional, siswa yang mengalami kecemasan tinggi dan sangat tinggi, dan bersedia menjadi responden. Tehnik pengambilan sampel yang digunakan peneliti adalah purposive sampling yaitu penentuan subjek sesuai karakteristik yang peneliti kehendaki. Subjek akan disesuaikan dengan tujuan penelitian.

5. Data dan Sumber Data

Sumber data primer didapat dari responden dan sumber data sekunder didapat dari informan. Dalam penelitian ini respondennya yaitu siswa kelas IX A dan kelas IX C yang mengalami kecemasan tinggi dan sangat tinggi dalam menghadapi Ujian Nasional yang bersekolah di SMPIT Ukhuwah Banjarmasin. Sedangkan Informan dalam penelitian ini 
adalah pengajar atau guru di SMPIT Ukhuwah Banjarmasin serta pihak lainnya yang dapat memberikan informasi terkait penelitian ini.

\section{Teknik Pengumpulan Data}

Penelitian ini hanya menggunakan satu skala yakni skala kecemasan karena dalam penelitian ini peneliti melakukan intervensi kepada subjek, dengan memberikan perlakuan kepada subjek untuk membaca zikir al-Ma'tsurat dan terjemahannya.

\section{Instrument Penelitian}

Alat ukur yang digunakan peneliti untuk mengukur kecemasan siswa menghadapi Ujian Nasional dibuat sendiri oleh peneliti berdasarkan komponen-komponen yang ada di definisi operasional yang kemudian dideskripsikan lewat indikator yang ada di blue print. Adapun komponen kecemasan yang peneliti maksud di sini adalah psikologis, kognitif dan fisiologis. Model skala ini menggunakan model skala likert. Adapun hipotesis dalam penelitian ini yaitu zikir al-Ma'tsurat dan terjemahannya dapat mempengaruhi penurunan kecemasan siswa menghadapi Ujian Nasional di SMPIT Ukhuwah Banjarmasin.

\section{Teknik Pengolahan dan Analisis Data}

Teknik pengolahan data dalam penelitian ini dimulai dari proses editing, skoring, dan kategorisasi. Analisis data pada penelitian ini adalah analisis statistik. Analisis statistik digunakan untuk menganalisis data berupa angka-angka. Analisis data hasil penelitian, dimaksud untuk mengetahui hipotesis yang sudah dirumuskan peneliti. Untuk mengetahui hal tersebut peneliti menggunakan tehnik analisis Uji beda $t-$ test. Adapun Uji beda t-test yang digunakan adalah paired sample test (variabel yang berhubungan), yakni uji $\mathrm{t}$ berpasangan merupakan salah satu metode pengujian hipotesis dimana data yang digunakan tidak bebas atau berpasangan

\section{Hasil}

\section{Sejarah Berdirinya SMPIT Ukhuwah Banjarmasin}

Yayasan Ukhuwah Banjarmasin sejak tahun ajaran 2007/2008 mendirikan SMP Islam Terpadu (SMPIT) Ukhuwah Banjarmasin, setelah berhasil mengembangkan pendidikan TK 
dan SD Islam Terpadu Ukhuwah Banjarmasin. Fenomena yang menarik adalah lulusan pertama SD Islam Terpadu Ukhuwah Banjarmasin pada tahun ajaran 2006/2007 semuanya lulus dengan hasil yang sangat menggembirakan dan dari 62 orang siswa lulus dengan nilai UAS rata-rata di atas 80 dan semuanya hafal al-Qur'an juz 30 dengan tartil.

Kesuksesan tersebut kemudian memicu tumbuhnya keinginan kuat bagi orangtua wali murid agar Yayasan Ukhuwah Banjarmasin mendirikan pendidikan lanjutannya, yakni SMP. Sekolah Menengah Pertama Islam Terpadu (SMPIT) Ukhuwah Banjarmasin yang lahir tanggal 8 Januari 2007 memiliki visi untuk meluluskan siswa-siswi yang berakhlak, berprestasi, mandiri, dan berwawasan lingkungan. Sedangkan misinya adalah menjadi lembaga pendidikan berbasis dakwah, menjadi lembaga pendidikan percontohan, dan menjadi lembaga pendidikan berwawasan lingkungan. Berdasarkan Keputusan Tim Penilai Sekolah Badan Akreditasi Sekolah Kota Banjarmasin Nomor Seri Dp. 010669 tanggal 23 November 2010 SMPIT Ukhuwah Banjarmasin mendapat nilai Sertifikasi Akreditasi Kualifikasi A (Amat Baik).

\section{Uji Validitas dan Reliabilitas}

Uji validitas dilakukan peneliti kepada 52 siswa di SMPIT Ukhuwah Banjarmasin yang terdiri dari 26 siswi kelas IX B dan 26 siswa kelas IX D. Uji validitas ini dilakukan untuk mengetahui kevalidan sebuah skala kecemasan yang dibuat peneliti, skala kecemasan itu terdiri dari tiga aspek yakni psikologis, kognitif, dan fisiologis, dan di urai menjadi 45 item pernyataan. Setelah diuji cobakan, maka terdapat 5 item pernyataan yang gugur atau tidak valid dan 40 item yang valid. Uji reliabilitas dengan menggunakan program SPSS diperoleh hasil untuk skala kecemasan 0,919

\section{Pelaksanaan Penelitian}

Penelitian ini di awali dengan pretest yakni pemberian awal skala kecemasan yang sudah valid dengan tujuan untuk mengetahui seberapa banyak siswa yang mengalami kecemasan tinggi dan sangat tinggi. Pretest dilakukan peneliti kepada 28 siswa kelas IX C dan 24 siswi kelas IX A, padahal siswi kelas IX A berjumlah 25 namun pada saat pretest 1 
orang siswi tidak bisa hadir karena sedang bepergian keluar kota, sehingga jumlah keseluruhan siswa yang mengisi skala kecemasan saat pretest berjumlah 52 siswa.

Setelah melaksanakan pretest, selanjutnya peneliti menentukan model kategorisasi data penelitian berdasarkan hasil skor pretest skala kecemasan. Sistem kategori yang dipilih oleh peneliti adalah kategori jenjang untuk mengelompokan subjek kedalam kategorikategori yang terpisah. Secara jenjang menurut Kontinum. Kontinum terdiri dari lima jenjang yang bergerak dari sangat rendah ke sangat tinggi. Peneliti menggunakan kategorisasi hipotetik berdasarkan skor teoritik untuk menyusun kategori tersebut.

Tabel 2

Skor Hipotetik Skala Kecemasan

\begin{tabular}{cccc}
\hline Skor minimal & Skor maksimal & SD & Mean Hipotetik \\
\hline 40 & 160 & 20 & 100
\end{tabular}

Skala kecemasan terdiri dari 40 item yang masing-masng itemnya memiliki skor berkisar antara 1, 2, 3, dan 4. Skor tertinggi yang mungkin didapatkan adalah 160 (4 X 40) dan skor terendah yang mungkin didapatkan adalah 40 (1 X 40) sehingga rentang skornya adalah 120 (160-40). Rentang skor skala dibagi ke dalam enam satuan standar deviasi sehingga diperoleh $120 / 6=20$. Dengan demikian kategori normatif skor adalah sebagai berikut:

Tabel 3

Kategori Normatif Skor Kecemasan

\begin{tabular}{|c|c|c|c|c|}
\hline Rumus & & kor & & Kategori \\
\hline$X-3$ SD s/d X - 1,8 SD & 40 & - & 64 & Sangat rendah \\
\hline$X-1,8$ SD s/d X - 0,6 SD & 64 & - & 88 & Rendah \\
\hline$X-0,6$ SD s/d $X+0,6 S D$ & 88 & - & 112 & Sedang \\
\hline$X+0,6 \mathrm{SD} \mathrm{s} / \mathrm{d} X+1.8 \mathrm{SD}$ & 112 & & -136 & Tinggi \\
\hline$X+1.8$ SD s/d $X+3$ SD & 136 & & -160 & Sangat tinggi \\
\hline
\end{tabular}


Dari jumlah 52 siswa yang mengikuti pretest maka yang diambil peneliti untuk di intervensi atau diberikan perlakuan adalah siswa yang masuk dalam kategori cemas tinggi dan sangat tinggi saja

Tabel 4

Jumlah Kategori Normatif Skor Kecemasan Pretest

\begin{tabular}{lcc}
\hline \multicolumn{1}{c}{ Skor } & Kategori & Jumlah Siswa \\
\hline $40-64$ & Sangat rendah & 2 \\
$64-88$ & Rendah & 18 \\
$88-112$ & Sedang & 25 \\
$112-136$ & Tinggi & 7 \\
$136-160$ & Sangat tinggi & 0 \\
\hline & Jumlah & 52 \\
\hline
\end{tabular}

Berdasarkan data tersebut dapat dilihat bahwa jumlah siswa yang mengalami kecemasan tinggi berjumlah 7 orang siswa dan tidak ada siswa yang mengalami kecemasan sangat tinggi. Oleh karena itu siswa yang dijadikan peneliti sebagai subjek perlakuan atau intervensi berjumlah 7 orang siswa. Adapun jumlah skor kecemasan tinggi yang diperoleh oleh 7 orang siswa tersebut dapat dilihat pada tabel 5 .

Tabel 5

Jumlah Skor Kategori Kecemasan Tinggi Pretest

\begin{tabular}{cccc}
\hline Kelompok & Subjek & Skor Pretest & kategori \\
\hline & A & 119 & Tinggi \\
& B & 120 & Tinggi \\
Subjek & C & 112 & Tinggi \\
Eksperimen & D & 115 & Tinggi \\
& E & 125 & Tinggi \\
& F & 115 & Tinggi \\
\hline & G & $\mathbf{1 2 1}$ & Tinggi \\
\hline
\end{tabular}


Setelah tahap pretest dilakukan selanjutnya 7 orang siswa yang mengalami kecemasan tersebut mengikuti sesi intervensi selama 5 hari.

Tabel 6

Pelaksanaan Intervensi Pembacaan Zikir Al-Ma'tsurat dan Terjemahannya

\begin{tabular}{|c|c|c|c|}
\hline No & Hari & Sesi & Tujuan \\
\hline 1 & Hari I & 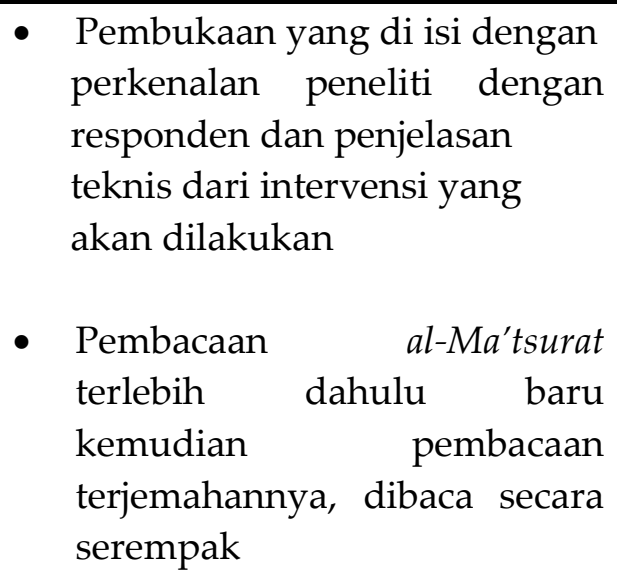 & 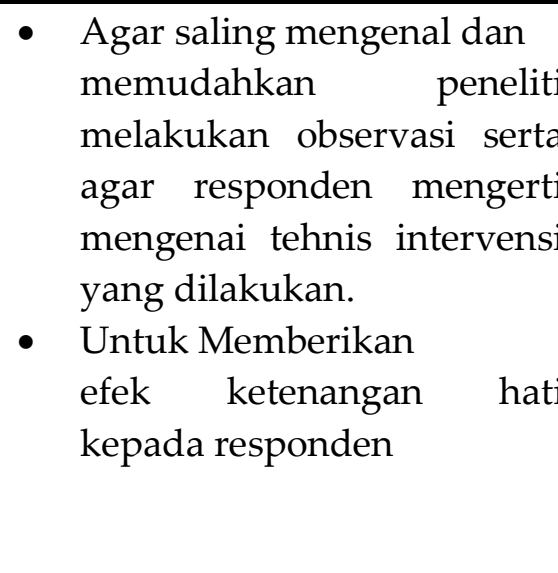 \\
\hline 2 & Hari II & $\begin{array}{l}\text { Pembacaan al- Ma'tsurat terlebih } \\
\text { dahulu baru kemudian } \\
\text { pembacaan terjemahannya dibaca } \\
\text { secara serempak. }\end{array}$ & $\begin{array}{l}\text { Untuk memberikan efek } \\
\text { ketenangan hati kepada } \\
\text { responden }\end{array}$ \\
\hline 3 & Hari III & $\begin{array}{l}\text { Pembacaan al- Ma'tsurat terlebih } \\
\text { dahulu baru kemudia pembacaan } \\
\text { terjemahannya, dibaca secara } \\
\text { serempak }\end{array}$ & $\begin{array}{l}\text { Untuk memberikan } \\
\text { ketenangan hati kepada } \\
\text { responden }\end{array}$ \\
\hline 4 & Hari IV & $\begin{array}{l}\text { Pembacaan al- Ma'tsurat terlebih } \\
\text { dahulu baru kemudian } \\
\text { pembacaan terjemahannya, } \\
\text { dibaca secara serempak }\end{array}$ & $\begin{array}{l}\text { Untuk memberikan } \begin{array}{r}\text { efek } \\
\text { ketenangan hati kepada } \\
\text { responden }\end{array} \\
\end{array}$ \\
\hline 5 & Hari V & $\begin{array}{l}\text { Pembacaan al-Ma'tsurat terlebih } \\
\text { dahulu baru kemudian } \\
\text { pembacaan } \\
\text { dibaca secara serempak }\end{array}$ & $\begin{array}{l}\text { Untuk memberikan } \text { efek } \\
\text { ketenangan hati kepada } \\
\text { responden }\end{array}$ \\
\hline
\end{tabular}

Tahap terakhir yang dilakukan peneliti setelah intervensi adalah melakukan postest, sesi postest dilakukan ketika subjek selesai membaca zikir al-Ma'tsurat dan terjemahannya pada hari ke V.

Berdasarkan skoring dari hasil postest yang dilakukan dengan menggunakan kategorisasi seperti perhitungan pretest, maka didapatlah hasil sebagai berikut: 
Tabel 7

Jumlah Skor Kategori Kecemasan Postest

\begin{tabular}{cccc}
\hline Kelompok & Subjek & $\begin{array}{c}\text { Skor } \\
\text { Postest }\end{array}$ & Kategori \\
\hline & A & 96 & Sedang \\
Subjek & B & 101 & Sedang \\
Eksperimen & C & 85 & Rendah \\
& D & 80 & Rendah \\
& E & 99 & Sedang \\
& F & 98 & Sedang \\
& G & 95 & Sedang \\
\hline
\end{tabular}

\section{Analisis Kuantitatif}

Deskripsi statistik digunakan untuk menganalisis data dengan cara mendeskripsikan atau menggambarkan data yang telah terkumpul sebagaimana adanya tanpa bermaksud membuat kesimpulan yang berlaku untuk umum atau generalisasi.

Tabel 8

Tabel Deskripsi Data Hasil Penelitian

\begin{tabular}{cccccc}
\hline Kelompok & Subjek & Skor & Kategori & Skor & Kategori \\
\hline & & Pretest & & Postest & \\
& A & 119 & Tinggi & 96 & Sedang \\
Subjek & B & 120 & Tinggi & 101 & Sedang \\
Eksperimen & C & 112 & Tinggi & 85 & Rendah \\
& D & 115 & Tinggi & 80 & Rendah \\
& E & 125 & Tinggi & 99 & Sedang \\
& F & 115 & Tinggi & 98 & Sedang \\
& G & 121 & Tinggi & 95 & Sedang \\
\hline
\end{tabular}

Data deskripsi hasil penelitian pada tabel 8 adalah skor dari pretest dan skor postest yang diberikan kepada 7 orang subjek. Data diatas menunjukkan adanya penurunan skor kecemasan pada saat postest, yakni setelah intervensi selesai dilakukan

Tabel 9

Deskripsi Statistik Subjek Penelitian 


\begin{tabular}{cccccr}
\hline & N & Minimum & Maximum & Mean & Deviation \\
Pretest & 7 & 112,00 & 125,00 & 118,1429 & 4,41318 \\
& & & & & \\
Postest & 7 & 80,00 & 101,00 & 93,4286 & 7,84978 \\
& & & & & \\
Valid N & 7 & & & & \\
(listwise) & & & & & \\
& & & & & \\
\hline
\end{tabular}

Tabel 9 menunjukkan adanya penurunan kecemasan dari nilai minimum yang cukup besar yakni 32,00 (112,00 - 80,00), dan nilai maximum yakni 24,00 (125,00 - 101,00), serta nilai mean yang juga menunjukkan adanya penurunan kecemasan antara sebelum intervensi dilakukan (pretest) dan setelah intervensi dilakukan (postest).

Uji normalitas merupakan uji prasyarat sebelum dilakukan pengujian hipotesis. Uji normalitas dilakukan untuk melihat penyimpangan frekuensi hasil penelitian dari frekuensi hipotetik. Jika tidak ada penyimpangan, maka variabel yang diuji memiliki sebaran normal.

Tabel 10

Uji Normalitas One Sample Kolmogorov-Smirnov Test

\begin{tabular}{|c|c|c|c|}
\hline & & Pretest & $\begin{array}{c}\text { Posttes } \\
t\end{array}$ \\
\hline $\mathrm{N}$ & & 7 & 7 \\
\hline \multirow{2}{*}{ Normal Parameters ${ }^{a, b}$} & Mean & 118,14 & 93,43 \\
\hline & $\begin{array}{c}\text { Std. } \\
\text { Deviation }\end{array}$ & 4,413 & 7,850 \\
\hline
\end{tabular}

\begin{tabular}{cccc} 
Most Extreme & Absolute &, 190 &, 294 \\
Differences & Positive &, 190 &, 167 \\
& Negative &,- 148 &,- 294 \\
Test Statistic & &, 190 &, 294 \\
Asymp. Sig. (2-tailed) & &, $200^{\mathrm{cd}}$ &, $069^{c}$ \\
\hline
\end{tabular}

Uji normalitas menggunakan tehnik kolmogorof-smirnov di atas menunjukkan $p>0,05$ yang berarti sebaran data pada tes awal dan akhir dinyatakan normal.

Analisis data yang digunakan untuk menguji diterimanya atau tidak hipotesis dalam penelitian ini menggunakan uji-t yaitu dengan paired samples-test, yaitu analisis dengan melibatkan pengukuran subjek yang sama terhadap suatu pengaruh atau perlakuan tertentu dengan bantuan soft ware SPSS versi 22. 
Tabel 11

Rangkuman Hasil Analisis Uji-T

\begin{tabular}{ccccccccc}
\hline & \multicolumn{9}{c}{ 95\% Confidence } & & Sig (2- \\
\hline & Mean & Std. & Std. & \multicolumn{2}{c}{ interval of the } & $T$ & df & Failed) \\
& & Devia & Error & \multicolumn{2}{c}{ difference } & & & \\
& tion & Mean & Lower & Upper & & & \\
Pretest - 24,714 & 5,908 & 2,233 & 19,250 & 30,178 & 11,068 & 6 & 0,000 \\
Postest & & & & & & & & \\
\hline
\end{tabular}

Uji beda yang dilakukan pada kelompok eksperimen mendapatkan nilai $t=11,068$ dan $p=0,000, p<0,01$, artinya ada perbedaan skor kecemasan yang sangat signifikan antara sebelum dan sesudah pembacaan zikir al-Ma'tsurat dan terjemahannya. Sehingga hipotesis penelitian ini dapat diterima.

\section{Diskusi}

Ujian Nasional merupakan salah satu sumber kecemasan bagi siswa, sebagaimana dalam bukunya Jeanne Ellis Ormrod yang berjudull Psikologi Pendidikan: Membantu Siswa Tumbuh dan Berkembang dijelaskan bahwa sumber kecemasan yang sering terjadi kepada siswa adalah salah satunya ujian kelas misalnya menjalani ujian penting, khususnya ujian yang mempengaruhi kesempatan naik kelas atau kelulusan.

Seseorang yang telah berada pada tingkat pendidikan SMP termasuk dalam fase perkembangan remaja awal, dimana terjadi transisi antara masa anak-anak dan masa dewasa yang mencakup perubahan biologis, kognitif, dan sosial-emosional. Usia yang masuk dalam masa remaja menurut Santrock dimulai kira-kira usia 10 sampai 13 tahun dan berakhir antara usia 18 dan usia 22 tahun. Perubahan biologis, kognitif, dan sosialemosional yang terjadi berkisar dari perkembangan fungsi seksual, proses berpikir abstrak, sampai pada kemandirian.

Menurut Soesilowindradini dalam bukunya yang berjudul Psikologi Perkembangan Masa Remaja, anak yang berada pada fase remaja awal biasanya mudah sekali mengalami cemas, takut khawatir dan anak remaja dalam masa ini tidak stabil keadaannya, kadang kesedihan tiba-tiba berganti dengan kebahagiaan atau sebaliknya, rasa percaya kepada diri sendiri 
yang berganti dengan rasa yang meragukan diri sendiri dan lain-lain. Keadaan yang tidak stabil ini adalah akibat dari perasaan yang tidak pasti mengenai dirinya.

Penelitian ini menemukan bahwa ketika peneliti melakukan pretest kepada sejumlah siswa kelas IX A dan IX C yang berjumlah 52 orang maka didapat skor kecemasan dari kategori sangat rendah, rendah, sedang, tinggi dan sangat tinggi, siswa yang masuk dalam kategori sangat rendah berjumlah 2 orang, kategori rendah berjumlah 18 orang, kategori sedang berjumlah 25 orang, kategori tinggi berjumlah 7 orang, dan tidak ada siswa yang masuk dalam kategori sangat tinggi.

Kecemasan yang dialami subjek dalam menghadapi Ujian Nasional dapat terlihat dari aspek psikis, fisik dan kognitif. Di mana dari aspek psikis dapat terlihat dari perasaan cemas, khawatir, takut, bingung yang dirasakan oleh siswa, sedangkan aspek kognitif misalnya susah konsentasi, sulit mengingat pelajaran, sedangkan dari aspek fisik seperti, merasa gelisah saat tidur, dada terasa sesak, jantung yang berdetak lebih cepat, diare, dan lelah.

Dari hasil penelitian ini terdapat perbedaan skor dari 7 orang siswa yang menjadi subjek yaitu skor penurunan kecemasan antara sebelum mengikuti pembacaan zikir al$M a^{\prime}$ tsurat dan terjemahannya dan setelah mengikuti pembacaan zikir al-Ma'tsurat dan terjemahannya. Penurunan skor dari kategori tinggi menjadi kategori rendah dan kategori sedang. Selain itu penurunan juga terlihat jelas dari penurunan nilai minimum yang cukup besar yakni 32,00 (112,00-80,00), dan nilai maximum yakni $24,00(125,00-101,00)$, serta nilai mean yang juga menunjukkan adanya penurunan kecemasan antara sebelum intervensi dilakukan (pretest) dan setelah intervensi dilakukan (postest), yakni sebesar 24,7147 dari nilai 118,1429 menjadi 93,4282 .

Intervensi pembacaan zikir al-Ma'tsurat dan terjemahannya pada penelitian ini bertujuan untuk memberikan efek ketenangan kepada subjek sehingga dapat mengurangi ataupun menurunkan kecemasannya dalam menghadapi Ujian Nasional, sebagaimana dalam Al-Qur'an Allah telah menjelaskan dan memberitahukan kepada manusia bahwa zikir dapat menentramkan jiwa, Allah menerangkannya dalam Q.S. al-Ra'd/3: 28 yang 
artinya: Yaitu orang-orang yang beriman dan hati mereka menjadi tenteram dengan mengingat Allah. Ingatlah hanya dengan mengingat Allah hati menjadi tentram.

Dalam tafsir al-Misbah di sebutkan bahwa ketentraman itu yang bersemi di dada mereka disebabkan karena zikrullah, yakni mengingat Allah atau karena ayat-ayat Allah yakni al-Qur'an yang sangat mempesona kandungan dan redaksinya. Kata zikir pada mulanya berarti mengucapkan dengan lidah, walaupun makna ini berkembang menjadi mengingat. Namun demikian mengingat sesuatu sering kali mengantar lidah menyebutnya, demikian juga menyebut dengan lidah dapat mengantar hati untuk mengingat lebih banyak lagi apa yang disebut-sebut itu. Kalau kata menyebut dikaitkan denga sesuatu apa yang disebut itu ialah namanya, karena itu ayat diatas dipahami dalam arti menyebut nama Allah. ${ }^{13}$

Zikir secara maksimal memiliki banyak manfaat bagi manusia diantaranya adalah untuk menemukan ketenangan hati dengan memperbanyak mengingat Tuhan dan memasrahkan kebutuhan hidupnya dengan sepenuh hati kepada Sang Maha Pencipta. Manfaat zikir yang berkaitan dengan kondisi kesehatan fisik dan psikis seseorang antara lain dapat menghilangkan kecemasan, kegundahan, kesulitan, dan depresi sehingga dapat mendatangkan ketenangan, kedamaian, kebahagiaan, dan kelapangan.

Zikir al-Ma'tsurat merupakan kumpulan wirid yang disusun oleh Syahid Hasan alBanna yang di dalamnya terdiri dari ayat-ayat pilihan dan lafal-lafal dari hadis Rasulullah Saw. yang menggunakan bahasa Arab dan kemudian terjemahannya ditulis dalam bahasa Indonesia. Hasan al-Banna merupakan pendiri dari Ikhwanul Muslimin, salah satu organisasi islam terbesar dan berpengaruh pada abad 20. Hasan Al-Bana mengahafal alQur'an pada usia 12 tahun, ia juga seorang mujahid dakwah, peletak dasar-dasar gerakan islam sekaligus sebagai pendiri dan pimpinan Ikhwanul Muslimin.

Intervensi pembacaan zikir al-Ma'tsurat dan terjemahannya dilakukan pada sore hari yang bertempat di ruang tamu kantor SMPIT Ukhuwah Banjarmasin, pembacaan zikir al$M a^{\prime}$ tsurat dan terjemahannya dilakukan secara serempak atau bersama-sama. Intervensi

\footnotetext{
${ }^{13}$ M Quraish Shihab, Tafsir Al-Mishbah: Pesan, Kesan Dan Keserasian Al-Qur'an Volume 1 (Jakarta: Lentera Hati, 2000). 271
} 
yang dilakukan selama 5 hari berturut-turut dilakukan dengan 7 orang subjek di mana mereka membaca al-Ma'tsurat yang berbahasa Arab terlebih dahulu secara bersama-sama kemudian selanjutnya diteruskan dengan terjemahannya.

Intervensi zikir al-Ma'surat dan terjemahannya yang dilakukan subjek selama 5 hari memiliki tingkat penurunan kecemasan yang cukup berbeda antara yang satu dengan yang lainnya, misalnya subjek A, B, E, F, G, sebelum intervensi dilakukan berada pada kategori kecemasan tinggi dan mengalami penurunan kecemasan menjadi kategori kecemasan sedang, sedangkan subjek C, dan D, pada saat pretest berada pada kategori tinggi dan setelah mengikuti intervensi menurun menjadi kategori kecemasan rendah.

Selama intervensi dilakukan di hari ke 4 subjek penelitian mengaku bahwa setelah mereka membaca zikir al-Ma'tsurat dan terjemahannya mereka merasakan perubahan suasana hati dalam diri mereka ke arah yang lebih baik, dan ketika mereka membaca terjemahannya mereka merasa bahwa zikir yang dibaca mereka ini memiliki makna yang sangat dalam.

Hasil penelitian ini sejalan dengan penelitian yang dilakukan oleh Ekka Nur Maisaroh dan Falasifatul Falah tentang Religiusitas Dan Kecemasan Menghadapi Ujian Nasional (UN) Pada Siswa Madrasah Aliyah, hasil penelitian mereka menyatakan bahwa adanya hubungan negatif yang sangat signifikan antara kecemasan menghadapi Ujian Nasional dengan religiusitas. Semakin tinggi religiusitas maka makin rendah kecemasan menghadapi Ujian Nasional, begitupula sebaliknya makin rendah religiusitas maka makin tinggi kecemasan menghadapi Ujian Nasional. ${ }^{14}$

Penelitian yang dilakukan oleh Istiyanah juga membuktikan bahwa zikir dapat menurunkan kecemasan siswa dalam menghadapi Ujian Akhir Sekolah. Adapun hasil dari penelitiannya ditemukan hubungan negatif yang signifikan antara zikir Al-Asma Al- Husna dengan kecemasan. ${ }^{15}$

\footnotetext{
${ }^{14}$ Maesaroh and Falah, "Religiusitas Dan Kecemasan Menghadapi Ujian Nasional (UN) Pada Siswa Madrasah Aliyah."

${ }^{15}$ Istiyanah, "Penagruh Intensitas Zikir Al-Asma Al-Husna Terhadap Kecemasan Siswa Menghadapi Ujian Akhir Sekolah Di Madrasah Tsanawiyah Naddatul Ulama 02 Al Ma'arif Boja" (Skripsi, Fakultas Dakwah IAIN Walisongo, 2010). 68
} 
Pada penghitungan menggunakan uji-t yaitu dengan paired samples-test, yaitu analisis dengan melibatkan pengukuran subjek yang sama terhadap suatu pengaruh atau perlakuan tertentu didapatlah hasil uji beda yang dilakukan pada kelompok eksperimen mendapatkan nilai $\mathrm{t}=11,068$ dan $\mathrm{p}=0,000, \mathrm{p}<0,01$, artinya ada perbedaan skor kecemasan yang sangat signifikan antara sebelum dan sesudah pembacaan zikir al-Ma'tsurat dan terjemahannya. Hasil tersebut menunjukkan bahwa zikir al-Ma'tsurat dan terjemahannya dapat menurunkan kecemasan siswa dalam menghadapi Ujian Nasional.

\section{Kesimpulan}

Berdasarkan hasil yang diperoleh dalam penelitian ini maka dapat dibuat kesimpulan bahwa setelah intervensi dilakukan atau postest, diperoleh data bahwa adanya penurunan kecemasan siswa dalam menghadapi Ujian Nasional. Penurunan skor dari kategori tinggi menjadi kategori rendah dan kategori sedang yang berarti bahwa zikir al-Ma'tsurat dan terjemahannya dapat mempengaruhi penurunan kecemasan siswa menghadapi Ujian Nasional di SMPIT Ukhuwah Banjarmasin dan itu berarti hipotesis yang diajukan peneliti dapat diterima.

\section{Saran}

Untuk peneliti yang ingin membuat penelitian yang sejenis maka disarankan agar Melakukan follow up hasil intervensi atau pembacaan zikir al-Ma'tsurat dan terjemahannya kepada subjek penelitian sehingga mengetahui konsistensi dari penurunan kecemasan tersebut. Hendaknya penelitian yang akan datang membuat kelompok kontrol untuk dijadikan kelompok pembanding, sehingga hasil penelitian dapat dibandingkan dengan kelompok yang tidak mendapat perlakuan. Terakhir, diharapkan penelitian yang akan datang juga hendaknya melakukan intervensi pembacaan zikir al-Ma'tsurat dan terjemahannya dengan jarak sesi yang lebih lama, agar subjek dapat lebih memahami dan lebih menghayati makna maupun isi dari zikir Al-Ma'tsurat yang mereka baca. 


\section{Kepustakaan}

Abdul Mujib, and Jusuf $\quad$ Mudzakir. Nuansa-Nuansa Psikologi Islam. Jakarta: PT RajaGrafindo Persada, 2002.

Az-Za'balawi, M Sayyid Muhammad. Pendidikan Remaja Antara Islam \& Ilmu Jiwa. Jakarta: Gema Insani, 2007.

Iin Tri Rahayu. Psikoterapi: Perspektif Islam Dan Psikologi Kontemporer. Malang: UIN Malang Press, 2009.

Istiyanah. "Penagruh Intensitas Zikir Al-Asma Al-Husna Terhadap Kecemasan Siswa Menghadapi Ujian Akhir Sekolah Di Madrasah Tsanawiyah Naddatul Ulama 02 Al Ma'arif Boja." Skripsi, Fakultas Dakwah IAIN Walisongo, 2010.

Jaelani, AF. Penyucian Jiwa (Tazkiyat Al-Nafs) \& Kesehatan Mental. Jakarta: Amzah, 2000. Maesaroh, and Falah. "Religiusitas Dan Kecemasan Menghadapi Ujian Nasional (UN) Pada Siswa Madrasah Aliyah." Jurnal Proyeksi 6, no. 2 (2011).

Mubarok, Achmad. Psikologi Qur'ani. Pustaka Firdaus, 2001.

Shihab, M Quraish. Tafsir Al-Mishbah: Pesan, Kesan Dan Keserasian Al-Qur'an Volume 1. Jakarta: Lentera Hati, 2000.

Teungku Muhammad Hasbi Ash Shiddieqy. Pedoman Dzikir Dan Do'a. Semarang: PT Pustaka Rizki Putra, 2002.

Wikipedia. “Zikir.” Accessed November 9, 2015. https://id.m.wikipedia.org/wiki/zikir. 